\title{
Ewa Cichowicz*
}

Agnieszka K. Nowak**

\section{INNOWACJE W DZIAŁALNOŚCI BANKOWEJ W ŚWIETLE PRZECIWDZIAŁANIA ZJAWISKU WYKLUCZENIA FINANSOWEGO W POLSCE}

\section{Wprowadzenie}

W związku z dynamicznym rozwojem rynków finansowych oraz procesami prowadzącymi do rozpowszechniania w ich ramach nowoczesnych technologii dochodzi do wdrażania kolejnych innowacji w sektorze bankowym. W szczególności mają one na celu poprawę konkurencyjności podmiotów i odpowiedź na zachodzące zmiany, dopasowanie się do oczekiwań i potrzeb potencjalnych klientów oraz możliwą redukcję kosztów. Jednocześnie okazuje się, że mogą stanowić element procesu przeciwdziałania wykluczeniu finansowemu społeczeństwa.

Warto zaznaczyć, że banki komercyjne w Polsce charakteryzuje stosunkowo wysoki poziom zastosowanych nowoczesnych technologii i narzędzi służących do oferowania produktów i usług finansowych oraz obsługi klientów. Z drugiej strony Polska jest krajem, który na tle krajów UE wyróżnia się niskim poziomem ubankowienia. Zgodnie z badaniami przeprowadzonymi na zlecenie NBP w $2012 \mathrm{r}$. w bankach i SKOK-ach posiadanie rachunku ROR (tzn. pierwszy stopień ubankowienia) deklarowało 73\% Polaków powyżej 15 roku życia, a na przełomie lat 2016 i 2017 - 83\% ${ }^{1}$. Podobne cechy szczególne dotyczące Polski widoczne są też w kolejnych stopniach ubankowienia (obejmujących zwłaszcza obszar oszczędności i zadłużania się).

Ponadto należy mieć na uwadze, że zjawisko relatywnie niskiego ubankowienia wraz z niskim poziomem obrotu bezgotówkowego odzwierciedlają zarazem poziom

* Kolegium Ekonomiczno-Społeczne, Szkoła Główna Iandlowa w Warszawie.

* Kolegium Zarządzania i Finansów, Szkoła Główna Iandlowa w Warszawie.

1 K. Pietraszkiewicz, wystąpienie na konferencji Związku Banków Polskich dotyczącej raportu „Reputacja sektora bankowego", 25 kwietnia 2017, http://tvn24bis.pl/pieniadze,79/polacy-lepiej-oceniaja-banki-Zwiazek-bankow-polskich,734720.html (dostęp 10.05.2017). 
wykluczenia finansowego społeczeństwa polskiego. Procesy ekskluzji oznaczają zaś ograniczenia $w$ dostępie i/lub korzystaniu $z$ usług instytucji finansowych (w tym przede wszystkim banków), co przekłada się na trudności w zaspokajaniu potrzeb jednostek i normalnym funkcjonowaniu w społeczeństwie. Dodatkowo, stwarzają ryzyko w wymiarze nie tylko indywidualnym, ale także postrzegane $\mathrm{z}$ perspektywy całego systemu społeczno-ekonomicznego. Wynika ono m.in. z konieczności korzystania przez osoby wykluczone finansowo $z$ usług podmiotów spoza regulowanego sektora finansowego (shadow banking), w tym z sektora fintech (przykładowo - platform sociallending).

Wobec powyżzego głównym celem opracowania jest próba udzielenia odpowiedzi na pytanie dotyczące znaczenia innowacji, które są wprowadzane przez banki w Polsce z punktu widzenia przeciwdziałania procesom związanym z wykluczeniem finansowym poszczególnych grup społecznych. W rozważaniach będą wzięte pod uwagę korzyści płynące z zastosowania nowych metod, które przyczyniają się do poprawy dostępności do oferty rynków finansowych.

Punktem wyjścia do realizacji zamierzeń badawczych będzie przegląd treści witryn internetowych wybranych banków działających w Polsce w celu ustalenia, jakie innowacje zostały wprowadzone w ramach oferowanych przez nie usług, które jednocześnie mogą wypłynąć na ograniczenie wykluczenia finansowego. Dla poszerzenia rozważań zostaną wykorzystane również informacje, jakie metody i narzędzia stosowane są przez inne instytucje (w tym o zasięgu międzynarodowym) w walce $z$ wykluczeniem finansowym. Ponadto przeprowadzona zostanie pogłębiona analiza literatury przedmiotu, która umożliwi rozważania o charakterze teoretycznym w zakresie znaczenia nowoczesnych rozwiązań wobec problemu ekskluzji finansowej.

\section{Innowacje finansowe}

W dobie dynamicznego rozwoju rynków finansowych oraz nowoczesnych technologii jednym $z$ podstawowych czynników determinujących przewagę konkurencyjną podmiotów i pozwalającą na wypracowanie zysku dla właścicieli są innowacje finansowe. Pojęcie to wywodzi się z ekonomicznego, klasycznego pojęcia innowacji, wprowadzonego przez J.A. Schumpetera, określonego jako wprowadzenie nowych: produktu, metody produkcji, rynku zbytu, źródła dostaw surowców, rozwiązań organizacyjnych oraz metod zarządzania ${ }^{2}$. W systemie ekonomicznym innowacja

2 J.A. Schumpeter, Teoria rozwoju gospodarczego, PWN, Warszawa 1960, s. 140. 
znosi stagnacyjną równowagę i jest źródłem rozwoju. Obok innowacji definiowane są równiéz wynalazek i imitacja, tworząc teorię „triady Schumpetera”. Określa ona trzy etapy wprowadzania innowacji, tzn. pierwszy - gdy powstanie wynalazek, drugi - gdy wynalazek zostanie wdrożony i stanie się innowacją, trzeci - gdy następuje upowszechnienie się innowacji poprzez powielenie rozwiązania przez innych (imitacja $^{3}$. Stąd widać, że według Schumpetera innowacją jest pierwotne wykorzystanie wynalazku. Taki pogląd prezentuje również E. Mansfield ${ }^{4}$. Przy czym, w dobie szybko rozprzestrzeniającej się informacji, często trudno określić, gdzie pojawiła się innowacja. Dlatego też obecnie częściej można spotkać się ze stwierdzeniem, że innowacją jest każdy wynalazek, który jest nowością dla jego użytkownika. Takie podejście reprezentowali L. Anderloni i P. Bongini 5 . Zostało ono również przyjęte w definicji OECD, która nie kładzie akcentu na jednorazowość i niepowtarzalność, lecz na fakt wdrożenia innowacji i wyróżnia jej cztery typy: produktowe, procesowe, marketingowe oraz organizacyjne $e^{6}$. Z kolei P.E. Drucker w swojej definicji innowacji nie zauważył jej odbiorcy, ale autora i rozumiał ją jako szczególne narzędzie przedsiębiorców, za pomocą którego czynią oni ze zmiany okazję różnych interesów lub usług7. Jednocześnie Drucker, a także E.J. Kane zwracają uwagę na przyczyny powstania innowacji i dzielą je na wywołane czynnikami wewnętrznymi (znajdującymi się wewnątrz każdej organizacji) bądź zewnętrznymi (związanymi ze zmianami w jej otoczeniu). Natomiast zdaniem autorek należy podkreślić jeszcze jeden aspekt innowacji (również zauważony przez Druckera), której źródłem jest ciężka i systematyczna praca, a nie jedynie geniusz i natchnienie?.

Innowacje finansowe są dwojako definiowane: w wąskim bądź szerokim ujęciu albo jako innowacje radykalne lub naśladownicze. W wąskim ujęciu definiowane są one jako nowe rozwiązania w obszarze produktów i usług (tzn. wprowadzenie nowych bądź modyfikacja już istniejących albo nowe ich zastosowanie), w szerokim obejmują nowe rozwiązania w każdym elemencie systemu finansowego (na rynkach

Ibidem, s. 104-116.

E. Mansfield, The Economics of Technological Change, W.W. Norton and Comp., New York 1968, s. 28.

L. Anderloni, P. Bongini, Is Financial Innovation Still a Relevant Issue?, [w:] Financial Innovation in Retail and Corporate Banking, red. L. Anderloni, D.T. Llewellyn, R.II. Schmidt, Edward Elgar, Cheltenham 2009.

6 OECD, Manual. Guidelines for Collecting and Interpreting Innovation Data, $3^{\text {rd }}$ ed., Eurostat, Oslo 2005, s. 48.

7 P.F. Drucker, Innowacje i przedsiębiorczość. Praktyka i zasady, PWE, Warszawa 1992, s. 36.

8 E.J. Kane, The Metamorphosis in Financial Services Delivery and Production, [w:] Commercial Bank Financial Management in the Financial-Services Industry, red. J.F. Sinkey Jr., $6^{\text {th }}$ ed., Prentice Hall, Upper Saddle River 2002, s. 33.

9 P.F. Drucker, Dyscyplina w podejściu do innowacji, „Harvard Business Review Polska” nr 11, styczeń 2004. 
finansowych, instytucjach finansowych i ich produktach, w infrastrukturze rynku czy w założeniach i normach ich działania $\left.{ }^{10}\right)^{11}$. Z kolei podział na innowacje radykalne i naśladownicze można utożsamiać $z$ schumpeterowskim podziałem na innowacje i imitacje ${ }^{12}$. Innowacje finansowe najczęściej przy tym utożsamia się z nowymi/zmodyfikowanymi produktami, czyli definiuje się je w wąskim ujęciu ${ }^{13}$. Jest to zgodne z podejściem definiowanym w teorii popytowej, według której źródłem innowacji jest popyt rynkowy ${ }^{14}$, co wpisuje się w koncepcję postrzegania innowacji m.in. w charakterze czynnika oddziałującego na poziom wykluczenia finansowego.

\section{Istota wykluczenia finansowego}

Wykluczenie finansowe po raz pierwszy zostało zdefiniowane w $1995 \mathrm{r}$. przez A. Leyshona i N. Thrifta jako procesy, które prowadzą do ograniczenia dostępu do systemu finansowego określonym grupom społecznym ${ }^{15}$. W definicji podanej w $2008 \mathrm{r}$. przez Komisję Europejską zostały natomiast uwypuklone inne aspekty, tj. negatywnego wpływu wykluczenia na jednostkę oraz fakt ograniczenia nie tylko dostępu, ale i korzystania $z$ usług finansowych (na ekonomicznie uzasadnionych warunkach) ${ }^{16}$. Zdaniem L. Anderloni wykluczenie finansowe jest definiowane w ujęciu węższym i szerszym. W węższym kładzie się nacisk na brak dostępu do rynków finansowych ze względu na specyfikę ich produktów. Brak tego dostępu nie ma wpływu na jednostkę i jej finanse, ale ogranicza możliwość pełnego uczestnictwa w życiu społecznym i ekonomicznym. Z kolei w podejściu szerszym zwraca się uwagę na wpływ ograniczenia dostępu na sytuację ekonomiczno-finansową osób w niekorzystnej

10 System finansowy w Polsce, t. 1, red. B. Pietrzak, Z. Polański, B. Woźniak, Wydawnictwo Naukowe PWN, Warszawa 2008, s. 20.

$11 \mathrm{~J}$. Błach, Innowacje finansowe $i$ ich znaczenie we wspótczesnym systemie finansowym - identyfikacja i systematyzacja problemu, Finansowy Kwartalnik Internetowy „e-Finanse” vol. 7, nr 3, 2011.

12 G. Michalczuk, Korzyści z wprowadzania innowacji finansowych w bankach w aspekcie kreowania ich konkurencyjności, ,Studia Ekonomiczne” nr 186, Innowacje a wzrost gospodarczy, cz. 1, Wydawnictwo Uniwersytetu Ekonomicznego w Katowicach 2014, s. 109.

13 M. Marcinkowska, Innowacje finansowe w bankach, „Acta Universitatis Lodziensis”, „Folia Oeconomica" 266,2012, s. 73 .

14 G. Michalczuk, op.cit., s. 103.

15 A. Leyshon, N. Thrift, Geographies of financial exclusion: financial abandonment in Britain and the United States, „Transactions of the Institute of British Geographers, New Series” Vol. 20, No. 3, 1995, s. 312-341.

16 Financial Services Provision and Prevention of Financial Exclusion, European Commission, March 2008. 
sytuacji społecznej, w tym o niskich dochodach ${ }^{17}$. Z kolei J. Buko podkreśla, że przy definiowaniu należy brać pod uwagę dwa aspekty, tj. ograniczenie korzystania z usług finansowych (wynikające $z$ niedostatecznego uświadomienia potrzeb finansowych) oraz ograniczenie możliwości korzystania z tych usług (ze względu na ich niedostosowanie do potrzeb klienta i/ lub barierę finansową) ${ }^{18}$.

Z perspektywy przyczyn wykluczenie finansowe można podzielić na związane z podejściem instytucji finansowych (przyczyny podażowe) i postawami jednostek (przyczyny popytowe). Do tych pierwszych E. Kempson i C. Whyley zaliczyli wykluczenie: ze względu na dostępność geograficzną (brak lub zamykanie placówek ze względu na małą atrakcyjność ich lokalizacji), ze względu na dostępność (wynikające $z$ przyjętego przez instytucję poziomu podejmowanego ryzyka) oraz marketingowe (brak zainteresowania ze strony instytucji grupą potencjalnych klientów). Do źródeł o podłożu popytowym zalicza się: wykluczenie ze względu na nieadekwatne do potrzeb klientów warunki usług, cenowe dla osób o niskich dochodach oraz samo wykluczenie (wynikające z przeświadczenia klienta, ze spotka się z odmową usługi bądź jej cena będzie zbyt wysoka) ${ }^{19}$. Do przyczyn wykluczenia finansowego A. Borcuch dodaje przyczyny społeczne, w tym: zmiany demograficzne, zmiany strukturalne na rynku pracy, nierówność dochodów, politykę fiskalną oraz liberalizację rynków finansowych (przyczyniającą się do poszerzenia oferty i złożoności produktów finansowych) ${ }^{20}$.

Biorąc pod uwagę rodzaj wykluczenia, B. Szopa i A. Szopa sformułowali szerszą definicją wykluczenia finansowego. Według nich oznacza ono stan ograniczenia lub braku zasobów finansowych, jakimi dysponują jednostki, który nie pozwala im na efektywne korzystanie $z$ usług finansowych, a także usług prawnych, ochrony zdrowia, edukacji czy kultury. Ogranicza, a najczęściej uniemożliwia posiadanie konta bankowego, a tym samym korzystanie $z$ usług finansowych ${ }^{21}$.

17 L. Anderloni, Access to Bank Account and Payment Services, [w:] New Frontiers in Banking Services. Emerging Needs and Tailored Products for Untapped Markets, red. L. Anderloni, M.D. Braga, E.M. Carluccio, Springer Verlag, Berlin-IIeidelberg 2007, s. 7.

18 J. Buko, Przeciwdzialanie wykluczeniu finansowemu jako element wspierania spójności spolecznej, „Nierówności Społeczne a Wzrost Gospodarczy" z. nr 18, Wydawnictwo Uniwersytetu Rzeszowskiego, Rzeszów 2011, s. $268-278$.

19 Financial Services Authority, In or Out?, A Literature and Research Review, „Consumer Research” No. 3, July 2000, [za:] M. Iwanicz-Drozdowska, Wykluczenie finansowe - powazny problem spoleczny, „MBA” 1, 2008, s. 3-11.

20 A. Borcuch, Instytucja wykluczenia finansowego w wymiarze platności bezgotówkowych, „Studia i Materiały. Miscellanea Oeconomicae” R. 16, nr 1, Wydział Zarządzania i Administracji Uniwersytetu Jana Kochanowskiego w Kielcach, Kielce 2012.

21 B. Szopa, A. Szopa, Wykluczenie finansowe a wykhuczenie spoleczne, „Zeszyty Naukowe” nr 11, Polskie Towarzystwo Ekonomiczne, Wydawnictwo Uniwersytetu Ekonomicznego w Krakowie, Kraków 2011, s. 6. 
W literaturze przedmiotu podkreśla się, że przyczyny wykluczenia finansowego wynikają najczęściej z tych samych przyczyn co wykluczenie społeczne. W tym przypadku do przyczyn przede wszystkim można zaliczyć: niski poziom wykształcenia (a tym samym - niską świadomość finansową), niski poziom dochodów, brak stałego zatrudnienia lub bezrobocie, samotne wychowywanie dzieci, podeszly wiek czy niepełnosprawność, a także miejsce zamieszkania w małej miejscowości i na wsi. Wśród przyczyn wskazuje się także brak efektywnej pomocy ludziom niezamożnym i znajdującym się w trudnej sytuacji materialnej. Odrębną grupę stanowią przyczyny wynikające $z$ postaw jednostek, a mianowicie brak zaufania do instytucji finansowych, obawa przed nowymi technologiami czy koniecznością korzystania $z$ komputerów, a także preferowanie płatności gotówkowych. Są to jednostki samowykluczone, często świadomie rezygnujące $z$ usług finansowych. Wśród nich przeważają ludzie starsi, którzy nie korzystają z usług finansowych, ponieważ wolą, aby emeryturę przyniósł im listonosz, z którym można porozmawiać. Kolejną grupę przyczyn wykluczenia finansowego należy upatrywać po stronie samych instytucji finansowych, wynikającą z wysokich kosztów ich usług, ze słabszej infrastruktury placówek instytucji finansowych w mniejszych miejscowościach i na wsiach oraz z braku oferty dla mniej zamożnych klientów.

\section{Przykłady przeciwdziałania wykluczeniu finansowemu za pomocą innowacji finansowych}

Konieczność przeciwdziałania wykluczeniu finansowemu została dostrzeżona już kilkanaście lat temu. Wiele z państw szuka rozwiązania tego problemu, często stosując podejścic innowacyjne. Przykładowo, w Holandii na podstawie umowy, w której jedną ze stron jest Ministerstwo Finansów, bank nie może odmówić otwarcia rachunku żadnemu klientowi. W Niemczech, Wielkiej Brytanii i we Włoszech udostępniane są tanie rachunki ROR, adresowane do klientów o najniższych dochodach. Szwecja gwarantuje wykluczonym dostęp do konta oszczędnościowego bez korzystania $z$ usług płatniczych. W wielu krajach organizowane są warsztaty i szkolenia, podczas których wyjaśnia się, jak planować budżet domowy i na czym polegają dane produkty finansowe ${ }^{22}$. Komisja Europejska systematycznie propaguje dostęp konsumentów do usług finansowych ${ }^{23}$.

22 A. Fandrejewska, Walka z wykluczeniem finansowym w Polsce, „Rzeczpospolita” 15 grudnia 2011, http:// www.rp.pl/artykul/769743-Walka-Z-wykluczeniem-finansowym-w-Polsce.html\#ap-7 (dostęp 30.09.2016).

${ }_{23}$ Zalecenie Komisji 2011/442/UE z dnia 18 lipca 2011 r. w sprawie dostępu do zwykłego rachunku platniczego, http://eur-lex.europa.eu/legal-content/PL/TXT/?uri-URISERV:em0050 (dostęp 30.09.2016). 
W Polsce również są podejmowane tego typu działania, na szczeblu krajowym i w poszczególnych instytucjach. W latach 2008-2011 opracowano „Program Rozwoju Obrotu Bezgotówkowego w Polsce na lata 2011-2013”. Mimo braku formalnego przyjęcia go przez Radę Ministrów jako programu rządowego, prace nad nim były kontynuowane. Ich wynikiem było opracowanie kolejnego programu na lata 2014-2020. Został on poprzedzony raportem na temat stanu rozwoju obrotu bezgotówkowego, na którego podstawie przyjęto jego główny cel - upowszechnienie obrotu bezgotówkowego, wspierany przez pięć celów szczegółowych (w tym ograniczenie wykluczenia finansowego i rozwój innowacyjnych instrumentów płatniczych). Z przygotowywanych przez NBP raportów dotyczących obrotu bezgotówkowego widać, że efekty podejmowanych działań są niedostateczne. Jeśli liczba transakcji bezgotówkowych w pojedynczym terminalu $\mathrm{POS}^{24}$ czy pojedynczą kartą płatniczą plasuje Polskę w połowie rankingu (odpowiednio 11 i 13 miejsce na 28 krajów), to liczba terminali POS na $1 \mathrm{mln}$ mieszkańców oraz transakcji kartami płatniczymi na 1 mieszkańca stawia kraj na dalekich pozycjach (odpowiednio na 24 i 19) ${ }^{25}$. Zwiększenie obrotu bezgotówkowego w Polsce wymaga technologicznego rozwoju rynku płatności, ubankowienia społeczeństwa oraz ewolucji jego nawyków płatniczych ${ }^{26}$. O ile zmiany technologiczne w Polsce pozwalają na stworzenie nowoczesnego rynku płatności bezgotówkowych, o tyle zmiana przyzwyczajeń płatniczych wymaga działań edukacyjnych.

Działania banków na rzecz ograniczania wykluczenia finansowego przede wszystkim skupiają się na udostępnianiu produktów osobom zagrożonym wykluczeniem finansowym. $Z$ danych NBP wynika, że $57 \%$ osób po 65 roku życia nie posiada rachunku bankowego, w grupie 55-65 lat - 32\% (dla porównania w grupie 35-44 lata -4\%). Jednocześnie systematycznie rośnie liczba emerytów, którzy korzystają z ROR-ów ${ }^{27}$. Banki, chcąc zachęcić seniorów, oferują im dedykowane konta, które dopasowane są do potrzeb i możliwości finansowych osób starszych. Przykładem

24 Terminal POS - urządzenie instalowane w punktach handlowo-usługowych, wykorzystywane do kontaktu $\mathrm{z}$ bankiem, za pośrednictwem centrum autoryzacyjnego w celı rozliczenia transakcji, gdy klient płaci kartą platniczą. M. Górnisiewicz, R. Obczyński, M. Pstruś, Bezpieczeństwo finansowe w bankowości elektronicznej - przestepstwa finansowe zwiazane z bankowościa elektroniczna. Poradnik klienta ustug finansowych, KNF, Warszawa 2014, http://www.knf.gov.pl/Images/Bezp_finansowe_tcm75-39005.pdf (dostęp 30.09.2016).

25 Dane za 2014 r. Raport NBP, Porównanie wybranych elementów polskiego systemu platniczego z systemami innych krajów Unii Europejskiej za 2014r., Departament Systemu Płatniczego, Warszawa, grudzień 2015, http://www.nbp.pl/systemplatniczy/obrot_bezgotowkowy/porownanie_UE_2014.pdf (dostęp 30.09.2016).

26 A. Tochmański, Zmiany na rynku płatności a obrót bezgotówkowy, NBP, Departament Systemu Płatniczego, Warszawa, 10 grudnia 2014.

27 Na wzrost ubankowienia ludzi starszych w Polsce może mieć wpływ naturalne przesunięcie demograficzne, polegające na umieraniu najstarszych (i najmniej ubankowionych), a wejście do tej grupy osób, które 
takich ROR-ów są: konto Aktywni 50+ (Bank Zachodni BZ WBK SA), Konto Słoneczne (Getin Bank SA), Konto Pogodne (PKO BP SA), Plan Senior (BGZ SA), dbKoneser (Deutsche Bank Polska SA) oraz Konto Nestor (Bank Pocztowy SA). Warunkiem ich otwarcia jest ukończenie 50 roku życia, 55+, 60+ czy wylegitymowanie się jednym ze świadczeń z ZUS, tj. emeryturą bądź rentą. Ważne jest to, że za ich prowadzenie banki albo nie pobierają prowizji, albo prowizja ta jest relatywnie niska, a także zapewniają dostęp do wszystkich bankomatów w kraju lub relatywnie dużej ich liczby. Do kont seniorów dedykowane są także dodatkowe korzyści, np. pakiet ubezpieczeń assistance, program rabatowy w aptekach, wyższe oprocentowanie ROR-u, moneyback (często za zakupy w aptekach) oraz możliwość zamówienia bezpłatnego dostarczenia gotówki do domu - przez listonosza. Nie wszystkie banki proponują seniorom dedykowane ROR-y, w większości z nich osoba w wieku 50+ może skorzystać ze standardowej oferty. Nie oznacza to jednak, że jest ona mniej korzystna. Czy jednak banki są istotnie zainteresowane obsługą tej grupy klientów? Emeryci mają stałe źródło dochodów, zazwyczaj dobrą historię kredytową. Jeżeli zaciągają pożyczki czy kredyty, to terminowo je spłacają. Rośnie więc liczba banków, które oferują konta dla osób starszych. Ale są i wyjątki. Bank Pocztowy SA w lipcu 2015 r., w ramach „uproszczenia oferty” i wprowadzenia jednolitego Konta Zawsze Darmowego, wycofał Konto Nestor. Oferta ta mogła istotnie przyczynić się do ubankowienia osób starszych, ponieważ bank w oddziałach pocztowych posiada rozwiniętą sieć placówek, a w usługach Konta Nestor było preferowane przez seniorów bezpłatne dostarczenie gotówki do domu przez listonosza.

Oferty banków dla ludzi młodych również są rozbudowane. Banki oferują ROR-y już od 13 roku życia (za zgodą rodziców/prawnych opiekunów), różna jest tylko górna granica wiekowa, ale nie przekracza ona 30 roku życia (Pekao SA). Konta najczęściej są zwolnione z opłat, z wyjątkiem opłaty za kartę: od 4zł (PKO BP SA, Bank Millenium SA) do 7 zł (ING BŚ SA), przy czym przy aktywnym korzystaniu $z$ konta opłata ta jest anulowana. Darmowe wypłaty $z$ bankomatów możliwe w sieci banku albo we wszystkich bankomatach w Polsce (mBank SA i ING BŚ SA). Tym, co rozróżnia oferty ROR dla młodych, są usługi dodatkowe, których gama jest różna i może stanowić dodatkowy bodziec do ich otwarcia. Przykłady to: 100zł premii za otwarcie konta (ING BŚSA), karta płatnicza z dowolnym zdjęciem za 0zł (PKO BP SA, ING BŚ SA), 10 darmowych biletów do kina za płatności kartą (PKO BP SA) czy zwrot za zakup legitymacji ISIC za 79 zł (Bank Millenium SA).

w poprzednim pomiarze byly już ubankowione. T. Koźliński, Zwyczaje płatnicze Polaków, NBP, Departament Systemu Płatniczego, Warszawa, maj 2013. 
Brakuje natomiast ofert dla osób o niskich zarobkach lub bezrobotnych. Wynika to z nałożenia się dwóch czynników: niskiego poziomu dochodu rozporządzalnego oraz braku stabilnego jego źródła (bądź braku źródła). Stąd wydaje się, że ubankowienie tych osób może być głównie realizowane za pomocą mikrofinansów. Jest to segment finansów, adresowany do ubogich grup społeczeństwa, którego celem jest udostępnienie najbiedniejszym środków, pozwalających na samozat rudnienie i przyczyniających się do ograniczenia ekskluzji finansowej i społecznej. Ich idea wywodzi się z Azji, ale systematycznie wykorzystywana jest na innych kontynentach, w tym w Europie ${ }^{28}$. W ramach mikrofinansów dostępnych jest wiele produktów, a przede wszystkim mikrokredyt. W Polsce banki nie działają zgodnie z ideą mikrofinansów ${ }^{29}$. Jedynie SKOK-i, ze względu na przynależność do Ŝwiatowej Rady Unii Kredytowych, której jednym z celów jest promowanie dostępu mikroprzedsiębiorstw do produktów kredytowych i oszczędnościowych ${ }^{30}$, częściowo realizują cele mikrofinansowe.

Jeżeli chodzi o działania instytucjonalne na rzecz mikrofinansów, to w UE została wydana decyzja Parlamentu Europejskiego i Rady (UE) ustanawiająca Europejski Instrument Mikrofinansowy na rzecz zatrudnienia i włączenia społecznego Progress ${ }^{31}$. Jego celem jest zwiększenie dostępu do mikrokredytów osobom zakładającym lub rozwijającym działalność gospodarczą w UE w celu wzrostu zatrudnienia i ograniczenia wykluczenia społecznego ${ }^{32}$. Komisja Europejska wspiera też mikrofinanse za pośrednictwem lokalnych instytucji finansowych, w ramach programów unijnych ${ }^{33}$.

Obok działań o charakterze ogólnounijnym widoczne są też inicjatywy podejmowane w danych krajach. Przykładowo, we Francji fundusz pożyczkowy Adie (dofinansowywany przez państwo) wspomaga samozatrudnienie wśród najuboższych warstw społecznych. W Holandii i w Niemczech, przy udziale sektora publicznego i prywatnego, podejmowane są inicjatywy, dzięki którym możliwe jest uzyskanie

28 J. Fila, Instytucjonalno-instrumentalne aspekty mikrofinansów na przykładzie mikrofinansowania Progress, http://zif.wZr.pl/pim/2013_2_1_9.pdf (dostęp 30.09.2016).

${ }_{29}$ Idea stworzona przez Muhammad Yunus, $w$ ramach projektu Grameen Bank, zgodnie $z$ którą nie można odmówić kredytu z powodu tego, że ktoś jest biedny, http://www.grameenfoundation.org/ (dostęp 30.09.2016).

30 http://www.uwcc.wisc.edu/icic/orgs/intl/woccu.html (dostep 30.09.2016).

31 Decyzja Parlamentu Europejskiego i Rady (UE) nr 283/2010/UE z dnia 25 marca 2010r. ustanawiająca Europejski Instrument Mikrofinansowy na rzecz zatrudnienia i właczenia społecznego Progress, DzUrz. UE z 7 kwietnia 2010r., nr L 87/1 oraz Rozporządzenie Parlamentu Europejskiego i Rady (UE) nr 1296/2013 $z$ dnia 11 grudnia 2013 r. w sprawie programu Unii Europejskiej na rzecz zatrudnienia i innowacji społecznych („EaSI”) i zmieniające decyzję $\mathrm{nr}$ 283/2010/UE ustanawiającą Europejski instrument mikrofinansowy na rzecz zatrudnienia i włączenia spolecznego Progress, DzUrz. UE L 347/238 z 20 grudnia 2013, http:// eur-lex.europa.eu/legal-content/PL/TXT/PDF/?uri-CELEX:32013R1296\&from=PL (dostęp 30.09.2016).

32 http://ec.europa.eu/social/main.jsp?langId pl\&catId = 836 (dostęp 30.09.2016).

33 Są to banki, towarzystwa gwarancyjne albo inwestorzy kapitałowi, http://ec.europa.eu/contracts_grants/ microfinance_pl.htm (dostęp 30.09.2016). 
pożyczki na rozpoczęcie działalności gospodarczej. Wielka Brytania i Finlandia nie posiadają regulacji dla tego typu inicjatyw, ale dopuszczają zwolnienia oraz ulgi podatkowe na rzecz finansowania rozwoju społeczności ${ }^{34}$. W Polsce również powoływane są instytucje oferujące mikrokredyty. Można do nich zaliczyć m.in. Fundusz Mikro założony przez Polsko-Amerykański Fundusz Przedsiębiorczości (PAFP) ${ }^{35}$ czy Polsko-Amerykański Fundusz Pożyczkowy Inicjatyw Obywatelskich (PAFPIO) ${ }^{36}$. Z kolei Fundacja Rozwoju Polskiego Rolnictwa (FRPR) ${ }^{37}$ oraz Fundacja Wspomagania Wsi (FWW) udzielają wsparcia ludności z terenów wiejskich zagrożonych bezrobociem. Przykładowo FWW od 1999 r. udzieliła ponad 17 tys. pożyczek na kwotę łączną ponad $190 \mathrm{mln} \mathrm{z}^{38}$.

Z kolei przykładem innowacji w obszarze technologii, mającej na celu ograniczenie wykluczenia finansowego, jest biometria. To technika dokonywania pomiarów organizmów żywych. Pozwala na rozpoznanie człowieka za pomocą wzorców biometrycznych. W tradycyjnej bankowości identyfikacja klienta odbywa się za pomocą dokumentu tożsamości, karty identyfikacyjnej i numeru PIN czy złożenia podpisu. W tych przypadkach istnieje duże zagrożenie podszycia się nieuprawnionej osoby. Przy wzorcach biometrycznych oszustwo jest praktycznie niemożliwe. Dlatego też bankowość biometryczna może być wykorzystana przy wypłacie świadczeń społecznych. Konieczne jest tylko jednorazowe wprowadzenie danych biometrycznych osoby uprawnionej do świadczeń. Po ich wprowadzeniu pobierający świadczenia, w dowolnym momencie, mogą dokonać wypłaty środków z bankomatu ${ }^{39}$. Biometria została po raz pierwszy wprowadzona w Polsce w 2010r. w Podkarpackim Banku Spółdzielczym (PBS) ${ }^{40}$. W oddziale w Sanoku zainstalowano pierwszy w Europie i w Polsce bankomat wyposażony w czytnik biometryczny Finger Vein ${ }^{41}$. Do zalet bankowości biometrycznej w procesie wypłat świadczeń należy zaliczyć: usprawnienie wypłat, zredukowanie nakładów czasowych, zredukowanie czasu oczekiwania na świadczenia, a przede wszystkim wzrost bezpieczeństwa. Jednocześnie osoby pobierające świadczenia, często wykluczone finansowo, zachęcone prostotą

34 B. Mikołajczyk, Mikrofinanse nowym wyzwaniem Unii Europejskiej (aspekt humanistyczny), „Annales. Etyka w życiu gospodarczym" vol. 12, nr 1, Archidiecezjalne Wydawnictwo Łódzkie, Łódź 2009, s. 91-98.

35 https://www.funduszmikro.pl (dostęp 30.09.2016).

36 http://pafpio.pl/ (dostęp 30.09.2016).

37 http://fdpa-funduszpozyczkowy.org.pl/ (dostęp 30.09.2016).

$38 \mathrm{http}: / /$ www.fundacjawspomaganiawsi.pl/index.php/pozyczki-dla-przedsiebiorcow (dostęp 30.09.2016).

39 Raport Biometryczny 2.0, „Bankowość biometryczna”, red. prow. T. Woszczyński, ZBP, Warszawa 2013, s. 48

40 Podkarpacki Bank Spóldzielczy jest największym bankiem spółdzielczym w Polsce; https://www.pbsbank.pl/historia (dostęp 1.10.2016).

${ }_{41}$ Technologia Finger Vein jest uznawana jako jedna $z$ bezpieczniejszych w bankowości biometrycznej. Raport Biometryczny 2.0, op.cit., s. 62. 
korzystania z urządzeń bankowych, będą miały mniejsze obawy przed skorzystaniem $z$ innych usług finansowych.

W przypadku ludzi mieszkających na terenach wiejskich bądź w małych miejscowościach do ich ubankowienia mogą się przyczynić takie innowacje technologiczne, jak mobilne wpłatomaty, udostępniane np. przez Idea Bank SA. Na razie są one dostępne w 13 miastach w Polsce i oferowane klientom prowadzącym własną działalność gospodarczą ${ }^{42}$, natomiast w przyszłości, w ramach procesu imitacji i upowszechnienia, mogą rozwiązać problem braku placówek bankowych na wsi i w malych miastach.

Ważnym uzupełnieniem działań na rzecz przeciwdziałania ekskluzji finansowej jest edukacja ekonomiczna. Wśród jej przejawów można wskazać na wiele innowacyjnych rozwiązańt ${ }^{43}$ do których moźna zaliczyć: platformy i portale internetowe prowadzone przez banki komercyjne i NBP, aplikacje wspierające zarządzanie finansami osobistymi, kampanie społeczne, wirtualne gry i symulacje czy nawiązywanie kontaktu $z$ wykorzystaniem mediów społecznościowych. Innym elementem o charakterze edukacyjnym jest doradztwo finansowe. Aby jednak mogło służyć ludziom zagrożonym wykluczeniem bądź już wykluczonym, powinno być tanie, a najlepiej - bezpłat ne. Przykładem tego typu inicjatywy może być bezpłat na Studencka Klinika Finansów, działająca przy Uniwersytecie Łódzkim czy Studencka Poradnia Finansowa (Uniwersytet Ekonomiczny w Katowicach). Aby uzyskać poradę, wystarczy dostarczyć dokumenty dotyczące sprawy oraz przyjść na konsultacje w celu przedstawienia problemu ${ }^{44}$. Inicjatywy w zakresie doradztwa są niezwykle istotne, ponieważ przy ograniczonej możliwości korzystania $z$ usług finansowych wykluczone grupy społeczne, szukając alternatywy, często stają się klientami firm z sektora shadow banking. Należy mieć przy tym na uwadze, że spółki wykorzystujące technologie fin tech przyczyniają się do wzrostu obrotu bezgotówkowego, ponieważ popularyzują usługi finansowe oferowane przez internet ${ }^{45}$, a według danych pozyczkaportal.pl w I półroczu 2016 r. prawie $30 \%$ wszystkich pożyczek online zostało zaciągniętych za pomocą urządzeń mobilnych. W marcu $2016 \mathrm{r}$. weszły w życie znowelizowane przepisy ustawy o zmianie ustawy o nadzorze nad rynkiem finansowym oraz niektórych

\footnotetext{
42 https://www.ideabank.pl/mobilny-wplatomat (dostep 30.09.2016).

43 I. Kuchciak, Innowacyjne koncepcje ubankowienia spoleczeństwa „Acta Universitatis Lodziensis”, „Folia Oeconomica" 266, 2012, s. 138-139.

44 Informacje zaczerpnięte z wywiadu z prof. nadzw. dr hab. I. Czechowską, Spójrzmy bliżej na Studencka Klinike Finansów, magazyn studencki „Forward” nr 18, Uniwersytet Łódzki 2016, s. 12-13.

45 T. Czechowicz, Bezgotówkowa ewolucja dzięki fintech, 11 kwietnia 2016, http://dyskusja.biz/finanse/ bezgotowkowa-ewolucja-dzieki-fintech-54285 (dostęp 30.09.2016).
} 
innych ustaw ${ }^{46}$, które istotnie ograniczają koszty pożyczek oraz związanych z nimi opłat, a przyjęta przez Komisję Europejską dyrektywa PSD II w sprawie usług płatniczych $w$ ramach rynku wewnętrznego ${ }^{47}$ przyczyni się do znacznej liberalizacji rynku usług finansowych w UE (dając dostęp podmiotom trzecim do danych klientów bankowych).

\section{Podsumowanie}

Zmniejszenie rozmiarów wykluczenia finansowego wymaga wielokierunkowych i regularnych działań. Jednym $z$ nich mogą być innowacje finansowe, mimo że często kojarzone są z nowoczesnymi rozwiązaniami, które mogą być barierą dla ludzi zagrożonych czy już dotkniętych wykluczeniem finansowym.

Zgodnie $z$ opinią prof. M. Iwanicz-Drozdowskiej na Zachodzie wykluczenie finansowe powoduje wykluczenie społeczne, $w$ Polsce jest przeciwnie ${ }^{48}$. Stąd zasadne jest połączenie działań na rzecz wykluczenia społecznego i finansowego, które muszą być podejmowane nie tylko przez instytucje finansowe, ale i przez państwo. Jednym $z$ rozwiązań jest edukacja finansowa. Może być ona narzędziem przeciwdziałającym wykluczeniu w przyszłości (np. dzieci i młodziėzy), może również prowadzić do zmniejszenia skali już występującego zjawiska (np. dzięki warsztatom finansowym prowadzonym w ramach działań socjalnych). Efekty przynoszą też szkolenia o tematyce szeroko rozumianych domowych finansów dla pracowników służb socjalnych, opiekujących się osobami wykluczonymi. Skutecznym narzędziem wsparcia może być bezpłatne doradztwo w zakresie zarządzania finansami osobistymi.

Często spotykanym postulatem jest też, by państwo wspierało instytucje finansowe oferujące tanie rachunki i nisko oprocentowane pożyczki. Oferta tanich ROR-ów pozwoliłaby na zbudowanie historii współpracy banku z klientem i ocenę jego zdolności do spłaty kredytu czy pożyczki. Tym bardziej że wspieranie inicjatyw promujących

46 Ustawa $z$ dnia 5 sierpnia 2015 r. o zmianie ustawy o nadzorze nad rynkiem finansowym oraz niektórych innych ustaw, DzU 2015, poz. 1357.

47 Dyrektywa Parlamentu Europejskiego i Rady (UE) 2015/2366 z dnia 25 listopada 2015r. w sprawie ustug płatniczych w ramach rynku wewnętrznego, zmieniająca dyrektywy 2002/65/WE, 2009/1 10/WE, 2013/36/ UE i rozporządzenie (UE) nr 1093/2010 oraz uchylająca dyrektywę 2007/64/WE, DzUrz. UE L 337/35, 23.12.2015, http://eur-lex.europa.eu/legal-content/PL/TXT/PDF/?uri=CELEX:32015L2366\&from =pl (dostęp 30.09.2016).

48 A. Fandrejewska, Potrzebne sa tanie ustugi dla niezamoznych, [w:] Rozdroża gospodarcze, odc. 15, Walka $z$ wykluczeniem finansowym, „Rzeczpospolita” 15 grudnia 201 1, http://www.nbp.pl/edukacja/dodatki_edukacyjne/Rzeczpospolita/rzeczpospolita_iii_dodatek_15.pdf(dostęp 30.09.2016). 
ograniczanie ekskluzji finansowej przez państwo mogłoby przynieść realne korzyści finansowe. Same koszty ponoszone przez ZUS z tytułu wypłaty świadczeń $w$ formie gotówki zamiast wpłaty na ROR-y wynoszą rocznie około $221 \mathrm{mln} z^{19}$. Na ubankowieniu mogą zyskać także seniorzy, bo przelew świadczenia na ROR zwiększa bezpieczeństwo ich środków.

Niezależnie od inicjatorów innowacji, najważniejsze jest, aby były one akceptowane przez ich adresatów. Dlatego też innowacje dedykowane ludziom zagrożonym bądź dotkniętym problemami społecznymi i finansowymi powinny być proste w obsłudze (jak bankomaty biometryczne), z minimalną ilością biurokracji, $z$ widoczną wartością dodaną (jak mikrofinanse czy ROR-y dla osób starszych i ludzi młodych), a przede wszystkim - tanie lub nawet darmowe.

\section{Literatura}

Błach J., Innowacje finansowe i ich znaczenie we wspólczesnym systemie finansowym - identyfikacja i systematyzacja problemu, Finansowy Kwartalnik Internetowy „e-Finanse” vol. 7, nr 3, 2011, s. 14-28.

Borcuch A., Instytucja wykluczenia finansowego w wymiarze platności bezgotówkowych, „Studia i Materiały. Miscellanea Oeconomicae” R. 16, nr 1, Wydział Zarządzania i Administracji Uniwersytetu Jana Kochanowskiego w Kielcach, Kielce 2012, s. 357-365.

Buko J., Przeciwdziałanie wykluczeniu finansowemu jako element wspierania spójności spotecznej, „Nierówności Społeczne a Wzrost Gospodarczy” z. nr 18, Uniwersytet Rzeszowski, Rzeszów 2011, s. 268-278.

Commercial Bank Financial Management in the Financial-Services Industry, red. J.F. Sinkey Jr., $6^{\text {th }}$ ed., Prentice Hall, Upper Saddle River 2002.

Czechowicz T., Bezgotówkowa ewolucja dzięki fintech, 11 kwietnia 2016, http://dyskusja. biz/finanse/bezgotowkowa-ewolucja-dzieki-fintech-54285

Decyzja Parlamentu Europejskiego i Rady (UE) nr 283/2010/UE z dnia 25 marca 2010 r. ustanawiająca Europejski Instrument Mikrofinansowy na rzecz zatrudnienia i włączenia społecznego Progress, DzUrz. UE nr L 87/1 z 7 kwietnia 2010 r.

Drucker P.F., Dyscyplina w podejściu do innowacji, „Harvard Business Review Polska” nr 11, styczeń 2004, s. 100-107.

Drucker P.F., Innowacje i przedsiębiorczość. Praklyka i zasady, PWE, Warszawa 1992.

49 Dane szacunkowe za 2015 r.; http://finanse.wp.pl/kat,1033719, title,Coraz-wiecej-emerytow-dostaje-emerytury-wprost-na-konto-To-ogromne-oszczednosci-dla-ZUS,wid,17769851, wiadomosc.html?tica$\mathrm{id}=117 \mathrm{f} 3 \mathrm{f}($ dostęp 30.09.2016). 
Dyrektywa Parlamentu Europejskiego i Rady (UE) 2015/2366 z dnia 25 listopada 2015 r. $\mathrm{w}$ sprawie usług płatniczych $w$ ramach rynku wewnętrznego, zmieniająca dyrektywy 2002/65/WE, 2009/110/WE, 2013/36/UE i rozporządzenie (UE) nr 1093/2010 oraz uchylająca dyrektywę 2007/64/WE, DzUrz. UE L 337/35 z 23 grudnia 2015, http:// eur-lex.europa.eu/legal-content/PL/TXT/PDF/?uri=CELEX:32015L2366\&from=pl

Fandrejewska $\Lambda$., Potrzebne sa tanie ustugi dla niezamożnych, [w:] Rozdroża gospodarcze, odc. 15, Walka z wykluczeniem finansowym, „Rzeczpospolita” 15 grudnia 2011, http:// www.nbp.pl/edukacja/dodatki_edukacyjne/Rzeczpospolita/rzeczpospolita_iii_dodatek_15.pdf

Fandrejewska A., Walka z wykluczeniem finansowym w Polsce, „Rzeczpospolita” 15 grudnia 2011, http://www.rp.pl/artykul/769743-Walka-z-wykluczeniem-finansowym-w-Polsce.html\#ap-7

Fila J., Instytucjonalno-instrumentalne aspekty mikrofinansów na przykładzie mikrofinansowania Progress, http://zif.wzr.pl/pim/2013_2_1_9.pdf

Financial Innovation in Retail and Corporate Banking, red. L. Anderloni, D.T. Llewellyn, R.H. Schmid, Edward Elgar, Cheltenham 2009.

Financial Services Authority, In or Out?, A Literature and Research Review, „Consumer Research" No. 3, July 2000.

Financial Services Provision and Prevention of Financial Exclusion, European Commission, March 2008.

Górnisiewicz M., Obczyński R., Pstruś M., Bezpieczeństwo finansowe w bankowości elektronicznej - przestepstwa finansowe zwiąane z bankowościq elektroniczna. Poradnik klienta ustugfinansowych, KNF, Warszawa 2014, http://www.knf.gov.pl/Images/Bezp_ finansowe_tcm75-39005.pdf

Iwanicz-Drozdowska M., Wykluczenie finansowe - poważny problem społeczny, „MBA” 1, 2008, s. 3-11.

Koźliński T., Zwyczaje płatnicze Polaków, NBP, Departament Systemu Płatniczego, Warszawa, maj 2013.

Kuchciak I., Innowacyjne koncepcje ubankowienia spoleczeństwa, „Acta Universitatis Lodziensis”, „Folia Oeconomica” 266, 2012, s. 125-144.

Leyshon $\Lambda$., Thrift N., Geographies of financial exclusion: financial abandonment in Britain and the United States, „Transactions of the Institute of British Geographers, New Series" Vol. 20, No. 3, 1995, s. 312-341.

Mansfield E., The Economics of Technological Change, W.W. Norton and Comp., New York 1968.

Marcinkowska M., Innowacje finansowe w bankach, „Acta Universitatis Lodziensis”, „Folia Oeconomica" 266, 2012, s. 71-96. 
Michalczuk G., Korzyści z wprowadzania innowacji finansowych $w$ bankach $w$ aspekcie kreowania ich konkurencyjności, „Studia Ekonomiczne” nr 186, Innowacje a wzrost gospodarczy, cz. 1, Wydawnictwo Uniwersytetu Ekonomicznego w Katowicach 2014, s. $102-112$.

Mikołajczyk B., Mikrofinanse nowym wyzwaniem Unii Europejskiej (aspekt humanistyczny), „Annales. Etyka w życiu gospodarczym” vol. 12, nr 1, Archidiecezjalne Wydawnictwo Łódzkie, Łódź 2009, s. 91-98.

New Frontiers in Banking Services. Emerging Needs and Tailored Products for Untapped Markets, red. L. Anderloni, M.D. Braga, E.M. Carluccio, Springer Verlag, Berlin-Heidelberg 2007.

OECD, Manual. Guidelines for Collecting and Interpreting Innovation Data, Eurostat, $3^{\text {rd }}$ ed., Oslo 2005.

Pietraszkiewicz K., wystąpienie na konferencji Związku Banków Polskich dotyczącej raportu „Reputacja sektora bankowego”, 25 kwietnia 2017, http://tvn24bis.pl/pieniadze,79/ polacy-lepiej-oceniaja-banki-zwiazek-bankow-polskich,734720.html

Raport Biometryczny 2.0, „Bankowość biometryczna”, red. prow. T. Woszczyński, ZBP, Warszawa 2013.

Raport NBP, Porównanie wybranych elementów polskiego systemu płatniczego z systemami innych krajów Unii Europejskiej za 2014r., Departament Systemu Płatniczego, Warszawa, grudzień 2015, http://www.nbp.pl/systemplatniczy/obrot_bezgotowkowy/ porownanie_UE_2014.pdf

Rozporządzenie Parlamentu Europejskiego i Rady (UE) nr 1296/2013 z dnia 11 grudnia 2013 r. w sprawie programu Unii Europejskiej na rzecz zatrudnienia i innowacji społecznych („EaSI”) i zmieniające decyzję nr 283/2010/UE ustanawiającą Europejski instrument mikrofinansowy na rzecz zatrudnienia i włączenia społecznego Progress, DzUrz. UE L 347/238 z 20 grudnia 2013.

Schumpeter J.A., Teoria rozwoju gospodarczego, PWN, Warszawa 1960.

Spójrzmy bližej na Studencką Klinikę Finansów, wywiad z prof. nadzw. dr hab. I. Czechowską, magazyn studencki „Forward” nr 18, Wydawnictwo Uniwersytetu tódzkiego 2016, s. 12-13.

System finansowy w Polsce, t. 1, red. B. Pietrzak, Z. Polański, B. Woźniak, Wydawnictwo Naukowe PWN, Warszawa 2008.

Szopa B., Szopa A., Wykluczenie finansowe a wykluczenie społeczne, „Zeszyty Naukowe” nr 11, Polskie Towarzystwo Ekonomiczne, Wydawnictwo Uniwersytetu Ekonomicznego w Krakowie, Kraków 2011, s. 13-27.

Toch mański A., Zmiany na rynku platności a obrót bezgotówkowy, NBP, Departament Systemu Płatniczego, Warszawa, 10 grudnia 2014.

Ustawa $z$ dnia 5 sierpnia 2015 r. o zmianie ustawy o nadzorze nad rynkiem finansowym oraz niektórych innych ustaw, DzU 2015, poz. 1357. 
Zalecenie Komisji 2011/442/UEz dnia 18 lipca 2011 r. w sprawie dostępu do zwykłego rachunku płatniczego, http://eur-lex.europa.eu/legal-content/PL/TXT/?uri=URISERV:em0050

http://ec.europa.eu/contracts_grants/microfinance_pl.htm

http://ec.europa.eu/social/main.jsp?langId=pl\&catId=836

http://fdpa-funduszpozyczkowy.org.pl/

http://finanse.wp.pl/kat,1033719, title,Coraz-wiecej-emerytow-dostaje-emerytury-wprost-

-na-konto-To-ogromne-oszczednosci-dla-ZUS, wid,17769851, wiadomosc.html?ticaid= $117 \mathrm{f} 3 \mathrm{f}$

http://pafpio.pl/

http://www.fundacjawspomaganiawsi.pl/index.php/pozyczki-dla-przedsiebiorcow

http://www.grameenfoundation.org/

http://www.uwcc.wisc.edu/icic/orgs/intl/woccu.html

https://www.funduszmikro.pl

https://www.ideabank.pl/mobilny-wplatomat

https://www.pbsbank.pl/historia

\section{Innovations in Banking Activity in the Light of Counteracting the Phenomenon of Financial Exclusion in Poland}

The goal of this article is to answer the question on the importance of innovations introduced by banks in Poland from the perspective of counteracting the processes related to financial exclusion of social groups. Consequently, selected innovative solutions have been considered, contributing to improving the availability of banks' offer. To accomplish this goal, we conducted an in-depth analysis of the subject literature. On this basis, the most important concepts for the subject - innovation and financial exclusion - were analysed. Subsequently, the content of the websites of selected banks operating in Poland was reviewed. Thanks to this, it was possible to identify innovations that could help to limit financial exclusion. In addition, information of what methods and tools are used by other institutions (including international ones) in the fight against financial exclusion were also used.

Keywords: innovativeness, ICT, financial exclusion, financial education, commercial banks. 


\section{Les innovations dans le secteur bancaire à la lumière de la lutte contre le problème de l'exclusion financière en Pologne}

Lobjectif principal de ce texte est de répondre à la question de savoir quelle est l'importance des innovations introduites par les banques en Pologne du point de vue de la lutte contre le problème de l'exclusion financière des différents groupes sociaux. En effet, la sélection comprend des solutions innovantes qui contribuent à l'amélioration d'accessibilité à l'offre des entités opérant sur les marchés financiers. Pour atteindre notre objectif, nous avons mené tout d'abord une analyse détaillée de la littérature spécialisée. Sur sa base, nous avons traité les notions les plus importantes pour ce sujet, à savoir l'innovation et l'exclusion financière. Ensuite, nous avons examiné le contenu des sites Internet des banques sélectionnées opérant en Pologne. Cela nous a permis d'identifier des innovations qui peuvent avoir une influence sur la réduction de l'exclusion financière. De plus, nous avons pris en compte les informations sur les méthodes et outils utilisés par d'autres institutions (y compris à l'échelle internationale) pour lutter contre l'exclusion financière. La dernière partie de ce texte comprend les conclusions les plus importantes de notre étude.

Mots-clés: innovation, technologies modernes, exclusion financière, éducation financière, banque commerciale.

\section{Инновации в банковской деятельности в контексте противодействия феномену финансового исключения в Польше}

Главной целью статьи является попытка ответить на вопрос о важности инноваций, внедряемых банками в Полыше, с точки зрения противодействия процессам, связанным с финансовым исключением отдельных социальных групп. Следовательно, были приняты во внимание избранные инновационные решения, способствующие улучшению доступа к предложениям игроков финапсового рынка. Для достижения этой цели, во-первых, был проведен углубленный анализ литературы и проанализированы наиболее важные понятия - инновации и финансовое исключение. Затем исследовалось содержание веб-сайтов отдельных банков, дейст вующих в Полыше. Благодаря этому удалось выявить инновации, которые могут повлиять на ограничение финансового исключения. Кроме того, использовалась информация о том, 
какие методы и инструменты применяются другими учреждениями (в том числе международными) в борьбе с финансовым исключением. Наиболее важные выводы исследования обобщены в заключении работы.

Ключевые слова: инновационшость, ИКТ, финансовая изоляция, финансовое образование, коммерческие банки. 